\title{
National parliaments and EU economic performance policies. Impact defines involvement?
}

\section{Ton van den Brink}

To cite this article: Ton van den Brink (2018) National parliaments and EU economic performance policies. Impact defines involvement?, Journal of European Integration, 40:3, 309-324, DOI: 10.1080/07036337.2018.1450403

To link to this article: https://doi.org/10.1080/07036337.2018.1450403

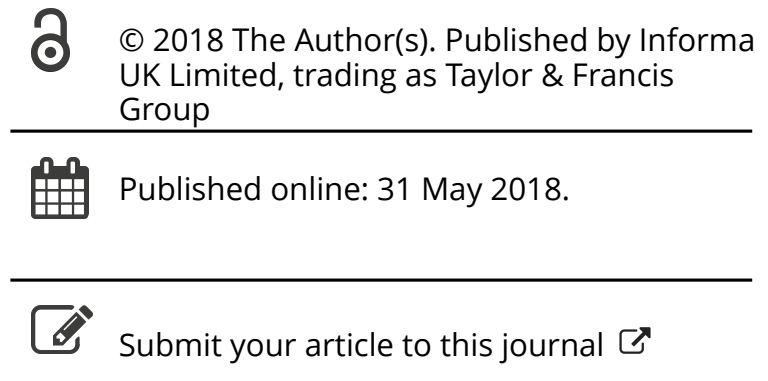

Џll Article views: 70

View Crossmark data ¿ 


\title{
National parliaments and EU economic performance policies. Impact defines involvement?
}

\author{
Ton van den Brink
}

Centre for Regulation and Enforcement in Europe (RENFORCE), School of Law, Utrecht University, Utrecht, The Netherlands

\begin{abstract}
In recent years, decision-making on economic performance policies macroeconomic stability and structural reforms - has evolved from a system based on Broad Economic Policy Guidelines into a full-fledged part of the European Semester, including the possibility to sanction Member States. This suggests an increased role for national parliaments to ensure the democratic legitimacy of EU decision-making. But this need for democratic legitimacy is qualified by the impacts of economic performance policies in and on the Member States. This contribution assesses these impacts by reviewing arguments derived from (a) the applicable legal framework and prior research that has been carried out and (b) by conducting a comparative analysis of the policy dialogues with Germany, France, the United Kingdom and the Netherlands in 2014 (based primarily on National Reform Programmes and Country Specific Recommendations). Next, an assessment is made of how parliaments in these countries have been involved concretely in economic performance policies.
\end{abstract}

\section{KEYWORDS}

European Semester; national parliaments; national reform programmes; country specific recommendations; economic performance

\section{Introduction}

National parliaments have become increasingly successful in securing their involvement in EU legislative processes. This has institutional reasons, such as the emergence of new mechanisms of scrutiny, but national parliaments also have an obvious and clear substantive interest to be involved in the EU's legislative processes: once adopted, EU legislation creates legal rights and obligations for Member States and citizens.

The challenge for national parliaments in EMU decision-making is of a totally different kind. Legislation has been adopted in this field as well, but this concerns mostly procedural and institutional requirements. Substantive economic policies, however, are developed in the framework of the European Semester (ES), the institutional dialogue between EU institutions (Commission, Council and European Council) and national institutions. This has been qualified as 'hands on executive power', in contrast to normative or rule-making authority (Curtin 2014). Thus, whereas the monetary union has been designed as a non-political, 
supranational and single-actor (primarily the European Central Bank) policy area, economic policy coordination is shaped as a multi-actor and multi-level decision-making arena. ${ }^{1}$

Two approaches to the ES have been key in the existing literature thus far. A first strand of research has sought to define the nature of the ES. Various scholars have characterized the ES along the dimensions of intergovernmentalism/supranationalism; 'hard' vs. 'soft' law and rules-based vs. coordination based cooperation (Armstrong 2013). A second strand of literature criticizes the weak democratic credentials of the ES. A central argument is that EU economic governance is dominated by executive actors, the decisions of which are insufficiently controlled by parliaments (e.g. Crum and Curtin 2015). The need to increase democratic legitimacy is now widely acknowledged and has also been argued from the transfer of economic powers from the Member States to the EU that should be accompanied with adequate mechanisms of democratic control (Juncker et al. 2015).

Typically, the literature on the nature of the ES characterizes the ES as a complex mixture of governance methods. A picture emerges of an intricate, hybrid governance system that integrates deliberative and more hierarchical elements. These elements have been identified and characterized and their interconnections assessed. This has been in particular relevant for national parliaments. The complexity of the governance system indeed renders it difficult to assess how it impacts the authority of national institutions to adopt economic policies. They remain in the driver's seat of economic policy-making but are at the same time subject to greater external discipline. Why, and if so: how, parliaments should be involved in EU economic policy coordination thus depends on the nature and the extent of such external discipline.

The central argument of this contribution is, thus, that the role of national parliaments, and even more fundamentally: the very need for democratic control on EU economic policies depends on, and is qualified by, the particular nature of EU economic policy-making. This leads to a research approach that contrasts with previous approaches according to which the democratic credentials of EU economic policy-making should be strengthened per se, regardless of the actual impact thereof. Exemplary for the latter approaches is Crum (2017) who has drawn a parallel between EU legislation and the ES to argue that both constrain national authorities and thus require democratic control, without addressing the fundamental differences in the way these constraints are shaped.

In this contribution, I will thus seek to connect the two strands of research to assess:

(1) how EU economic policies impact the Member States;

(2) the implications thereof for the role of national parliaments.

In line with the central approach of this special issue, both aspects must be assessed in light of throughput legitimacy. This enables zooming in on processes of economic policy-making and the roles of EU institutions and national actors therein. In doing so, this contribution assesses formal, legal structures which reveal the capacity of EU economic policies to impact the Member States and the potential of national parliaments to be involved in these policies. This includes factors such as the legal effects and consequences of these policies (most notably the possibility that sanctions may be imposed). The analysis furthermore addresses the issue how the various actors (most notably national governments, national parliaments and the European Commission) make use of their powers and potential to impact the Member States and how they influence economic policies. This necessitates an assessment of the roles of the different actors and of the actual content of EU economic 
performance policies to be able to examine to which extent such policies are actually designed at the EU level (or, rather, at the national level). Indeed, it matters how concrete and specific, but also how strictly formulated these policies are as this will eventually reduce or widen national parliaments' potential role and which effects they have in the Member States. In line with the conceptualization of throughput legitimacy in the broader context of this special issue, the throughput legitimacy perspective employed in this contribution encompasses a normative and an empirical dimension.

The analysis is limited to economic performance policies, i.e. the EU policies to prevent and address macroeconomic imbalances and policies on structural economic reforms. Thus, EU policies on public finances in the Member States are excluded. These policies differ substantially from the former type of policies, in particular in how they constrain the Member States. Although economic performance policies have to some extent evolved to resemble public finances policies more, e.g. by the introduction of the Macro-economic Imbalances Procedure, the differences between the two types of policies are still substantial (see Section 2). In line with the central argument of this contribution, this affects the need and the possibilities for democratic control.

The analysis is based on the main policy measures of EU economic performance policy-making: National Reform Programmes (NRPs) and Country Specific Recommendations (CSRs). These policy measures concern the basis for the coordination between EU and national institutions. As this contribution addresses the interplay between these institutions, it focusses primarily on parliamentary positions as a whole (i.e. majority decisions). Minority, party and/or individual MP positions are thus only considered if these are relevant to understand the outcomes of parliamentary decision-making as a whole. This equally explains why the analysis is primarily based on formal documents: the interplay between national and EU institutions and the coordination of economic policies resulting therefrom is mainly shaped on the basis of these policy measures and the legal and institutional framework of which they form part. The third important policy measure of the ES is the Annual Growth Survey (AGS). This measure relates to the European economy as a whole (although in part it focusses on the Eurozone only). This may impact national autonomy as well. Currently, however, the AGS only lists general priorities of a rather high level of abstractness. Moreover, it does not concern individual Member States. In any case, national parliaments lack direct opportunities to be involved in the adoption of the AGS.

The selection includes 4 Member States: Germany, the UK, France and the Netherlands. This selection allows a comparison between Eurozone Member States (Germany, France and the Netherlands) and a non-Eurozone Member State (the UK), and between bigger (Germany, the UK and France) and smaller (the Netherlands) Member States. The analysis is largely limited to lower houses since upper houses have a more limited political position (especially in France and the Netherlands). Furthermore, the year on which the analysis is based is 2014. It was at that time when economic governance policies started to gain traction. The new framework for the ES had been in operation for some years and, more importantly, the realization started to dawn that northern countries were facing serious economic, albeit not budgetary, problems. The focus on 2014 furthermore allows to take into account subsequent developments. The potential impact of EU economic performance policies is thus most likely to manifest itself with regard to these countries, in particular the Netherlands and Germany (inter alia in light of their high trade surpluses). This too explains why the analysis is limited to northern European Member States. The analysis in particular excludes Member States 
that have been subject to financial assistance programmes (the so-called'programme countries'). Their situation differs considerably from that of other Member States and falls outside the scope of the regular coordination mechanisms.

Hereafter, Section 2 takes a top-down perspective and discusses first the new system of economic governance in the EU and then advances arguments for a larger role of national parliaments therein. Section 3 takes a bottom-up perspective: it discusses the coordination processes and their actual impact on the economic policies of Germany, the Netherlands, France and the UK, taking into account the factors outlined above, and assesses the role of each national parliament in the respective policy dialogues. Section 4 synthesizes the results of the previous sections paragraph, and discusses to what extent more parliamentary involvement is needed, and the factors on which that depends.

\section{The new system of economic governance and national parliaments}

Until 2011, EMU was marked by a double imbalance. The first, between supra-nationalized monetary policy and coordination-based economic policies is notorious and it is widely acknowledged to be one of the biggest flaws of EU economic governance. The imbalance between coordination of fiscal policies (public deficits and public debts) and economic reform policies has attracted less attention. Nevertheless, governance of the latter, based on a non-binding system of Broad Economic Policy Guidelines, differed significantly from fiscal policies as these are based on binding substantive rules and a governance framework that includes the Excessive Deficit Procedure (EDP) and the possibility to impose sanctions (although these have never been imposed in practice). A set of six EU legislative measures (the 'Six Pack') in 2011, and an intergovernmental treaty (the Treaty on Stability, Coordination and Governance, or 'Fiscal Compact') (Craig 2012) followed by another two EU regulations in 2013 (the 'Two Pack') fundamentally transformed EU economic governance, especially economic performance policies (Amtenbrink 2012). These policies are now subject to a similar institutional framework as fiscal policies.

They are brought together in the ES, the annual policy cycle introduced in 2010 to coordinate economic and budgetary policies and follow up on their implementation, as a response to the lack of coordination that became apparent during the recent financial and economic crisis (De Sadeleer 2012). National fiscal policies are articulated in Stability or Convergence Plans (the latter for non-Eurozone Member States) whereas Member States present their policies on economic performance in NRPs. The Commission and the Council respond to these NRPs in an integrated document, the CSRs. The ES is supplemented with enhanced surveillance mechanisms in case of problems: the EDP, already introduced in 1999 but amended later, and the Excessive Imbalance Procedure (EIP) introduced by the 'Six Pack'. Problems in the functioning of national economies are systematically identified and analysed and in case of severe issues the EIP may be triggered. This is the counterpart of the EDP and has the same potential to trigger sanctions (European Commission 2016a). Despite these 'harder' elements, economic policy coordination has been qualified as a system that still includes 'softer' elements and combines these with harder law mechanisms (Armstrong 2013).

Remarkably, this transformation of economic governance has hardly had effects on the formal position of national parliaments in the EU decision-making framework. Despite the fact that the Five Presidents, in their report from 2015 (Juncker et al. 2015), considered 
national parliaments crucial actors to shape Political Union and to contribute to 'genuine democratic accountability, legitimacy and institutional strengthening', major changes to their position in the system of economic governance are still missing. Instead, the presidents have proposed to make the interaction between the European Commission and the national parliaments more efficient. This would be particularly needed in light of the political judgements that are indeed made by the Commission (Barrett 2018). More systematic dialogues between the Commission and national parliaments should therefore be developed and parliaments should exercise their right - recognised in the legislative 'Two-Pack' - to invite the responsible Commissioner (Juncker et al. 2015, 17). These recommendations are, thus, limited in scope and do not specifically address economic performance policies. The right to convene the responsible Commissioner is even limited to the presentation of the Commission's opinion on draft budgetary plans or to its recommendations in Excessive Deficit Procedures (Article 7 (3) Regulation 473/2013/EU and article 3(8) Regulation 472/2013/ EU). However, the Five Presidents also called upon national governments to 'more systematically involve' national parliaments before the annual submission of National Reform and Stability Programmes (Juncker et al. 2015, 20). The involvement of national parliaments should, thus, be shaped along familiar lines: in relation to their respective governments.

The possible imposition of sanctions is a strong argument in favour of national parliaments' involvement. Since the entry into force of the legal framework elaborated above, intensified supervision (the Macroeconomic Imbalance Procedure) and ultimately the possible imposition of financial sanctions now applies to economic performance policies as well. In the field of fiscal and budgetary policies, no sanctions have ever been imposed, even if there has been reason to do so (on the effectiveness of the ES: Hallerberg, Marzinotto, and Wolff 2011). This has, admittedly, made the ES a 'non-constraining mechanism' (Maatsch 2017, 692). There are, however no guarantees that this will remain so. Indeed, the Commission may be more inclined to apply sanctions in the field of economic performance policies. In any case, the drawbacks of imposing financial sanctions on Member States that already perform badly with regard to their fiscal policies do not apply here.

Although sanctions may ultimately be imposed, it is still correct to qualify the current governance system in terms of dialogue and coordination. From the perspective of national parliaments there is a positive and a negative side to this. They may more easily ensure their input on economic plans as these are drafted by national governments. On the other hand, as said in the introduction, the multilevel and multi-actor system of coordination between various national and EU actors blurs responsibilities and the potential for clear parliamentary accountability thereby diminishes. Executive actors may shield themselves behind other actors and behind earlier steps taken in the decision-making process (Crum, Curtin, and Piattoni 2015, 83).

Economic performance policies include a wide variety of policies. At first, it may have seemed that these policies were merely supportive of budget policies and merely stimulated Member States to adopt economic policies with positive effects on public finances (Costamagna 2013). But EU economic performance policies have now become a self-standing pillar of EU economic governance. They now include recommendations to pursue social objectives as well, such as the reduction of poverty and the accessibility of affordable housing (Adnett 2001). Some scholars have argued that this 'socialization' of economic policies is not complete yet, and that a better balance between economic and social objectives should be struck (Zeitlin and Vanhercke 2014). By contrast, others have argued that even in case of 
conflict between economic and social objectives, the former do not necessarily trump the latter (Bekker 2014). In any case, balancing economic and social objectives takes these policies out of the technocratic domain and places them in the heart of political decision-making. Indeed, they concern redistributive policies (Maatsch 2017), which strengthens the need for democratic legitimacy. Moreover, even economic objectives themselves are defined in a wide sense. They include the modernisation of public administration and the functioning of judicial systems (Peña-Casas et al. 2015). Especially such recommendations, of which the impact on economic performance is more indirect, may conflict with other national policies. Recommendations to reduce administrative burdens on businesses may, for instance, include the removal of restrictions on access to and the exercise of regulated professions, but such restrictions may be justified from national public interests.

The scope of EU economic performance policies is, however, only one factor that determines the impact thereof on the Member States. The nature and the level of specificity of the Commissions' recommendations is an equally important factor. It also matters whether policies are indeed developed by EU institutions or, rather, formulated at the national level and perhaps only endorsed by EU institutions. In the latter case, it would make more sense for national parliaments to be involved in national policy-making. This requires analysis of how EU and national institutions actually interact within the ES. To this end, NRPs will be compared to CSRs. This may reveal whether EU institutions, most notably the Commission, base CSRs on NRPs or on their own assessment of the state of the national economy. The latter may be the case if CSRs contain stricter policy recommendations than those formulated in NRPs and/or if they address issues other than those dealt with in NRPs.

\section{The nature of economic performance policies: NRPs and CSRs}

In this empirical part, the actual impact of EU economic performance policies is examined, based on the contents of these policies as they appear from the main documents of the ES: the NRPs and the CSRs as well as the In-Depth Reviews (IDRs) which are carried out when problems in the functioning of national economies have been identified.

\subsection{Germany}

Germany was subject to the Macroeconomic Imbalances Procedure (MEIP) in 2014. The IDR issued by the Commission in March 2014 identified a number of imbalances in the German economy, although it considered none of these as excessive or ground for triggering next steps yet (European Commission 2014a). The Commission considered the trade account surplus the most serious imbalance, which required 'decisive policy action and monitoring'. In the NRP, The German government had discussed possible causes for the account surplus and ways to address it, such as an increase of public investments and a simplification of the legal framework for private investments.

The NRP was structured around (a) the implementation of earlier CSRs; (b) the achievement of the objectives set out in the Europe 2020 strategy and (c) the implementation of the Euro Plus Pact (Federal Ministry for Economic Affairs and Energy 2014). More than other governments did, the German government thus placed its reform plans in the broader context of the European legal structures and political plans, thereby underlining the position 
of national economic policies as a part of the wider EU economy and also as part of a continuous process of policy dialogue.

The German government explicitly addressed labour, energy and competitiveness policies (German Government 2014). Specific measures in the field of labour policies included an increase in labour force participation and raising wages. On energy policy, the German government elaborated its plan to transfer to economic efficient renewable energy sources and to coordinate energy policies with neighbouring countries. Competition should be increased, especially in some sectors of service provision and by increasing the value of public contracts open to procurement.

The Commission and the Council mirrored most of the measures outlined in the NRP (European Commission 2014b). The measures on the energy market were mostly endorsed. A notable difference, however, regarded planning regulations. The German government had contended that such regulations pursued overriding reasons of general interest and proved no obstacle to entry to the retail market. The Commission and Council disagreed with the German government and called for their removal. The issue of the account surplus translated into a recommendation to remove high taxes and social security contributions, especially for low-wage earners to foster domestic demand. This seems a rather modest recommendation given the severity of the account surplus problem as the Commission had elaborated it. The 2015 CSR indeed included a much broader and specific recommendation to address the account surplus: to increase public investment in infrastructure, education and research; to improve the efficiency of the tax system; and to ensure adequate public investment at all levels of government (European Commission 2015a). The recommendations on employment were probably the most elaborate and they were also quite specifically worded. Apart from the recommendations on low-wage earners, the employability of workers and the reduction of fiscal disincentives to work were suggested.

The NRP 2014 was only discussed in the plenary of the German Bundestag upon a motion from the Green party. The party criticized the CDU/CSU and the Socialist Party for not being truly committed to EU economic governance (Maatsch 2017, 702). The Green Party voiced concerns on the trade account surplus and urged the government to take the Commission's warning on the balance surplus as a starting point to increase private and public investment, to stimulate domestic demand and to design favourable tax measures for SMEs. This motion was rejected. The Green party also tabled a motion that the Government should take environmental, investment and innovation goals into account in the NRP for $2014 .^{2}$ This motion was not adopted either. No further discussions on the NRP and CSR could be found (as the minutes of committees such as the European Affairs Committee (Europa-Ausschuss- EAC) are not published).

The year after, in 2015, the political nature of the decision-making became stronger, with the government coalition being more reluctant to address the account surplus, and the Commission and -again- the Green Party being critical on that position (Maatsch 2017: 702). The Bundestag concluded that NRPs should be adopted in collaboration with the government after public debates in the relevant parliamentary committees and the plenary (Deutscher Bundestag 2015). It also proposed to strengthen the dialogue with the Commission by organizing meetings when the latter is preparing its CSR and a plenary debate after the adoption thereof. It is observed, however, that the German Bundestag is still underperforming in this regard (Kreilinger 2018). 


\subsection{The Netherlands}

As Germany, the Netherlands has been faced with macroeconomic imbalances for over a longer period as well, such as an account surplus, external competitiveness issues and public and private indebtedness. Thus, the Commission conducted an IDR, the results of which revealed that the high private sector debt and ongoing deleveraging, coupled with remaining inefficiencies in the housing market, constituted imbalances (European Commission 2014c). The Commission recalled that a relevant policy recommendation on the housing market had already been part of the 2012 and 2013 CSRs. Although the Commission viewed the large account surplus as an issue deserving attention as well, it did not consider it to raise 'immediate stability risks' (European Commission 2014c, 53).

In the 2014 NRP, the Dutch government elaborated the measures that had been set in motion to reform the housing market, especially the tax deduction system for mortgages and, albeit in a less specific manner, to the reforms of the rental market (Dutch Government 2014,17 ). Other measures regarded the pension system (a better inter- and intra-generational distribution of costs and benefits), improvements to the long-term health care system and measures to increase labour market participation.

The CSR, following the NRP, was adopted by the Council on 8 July 2014 (Council of the European Union 2014a) and did not deviate substantively from the Commission's proposal adopted on 2 June 2014 (European Commission 2014d). It addressed the same three issues (housing, pensions \& health care and employment) as those put forward by the Dutch government. In general, the Council and Commission endorsed the measures elaborated by the Dutch government. A quite positive assessment was made about the reforms of the pension system and on the labour market reforms, even though the EU institutions considered further measures needed and that the existing ones could only be fully assessed after having been fully implemented. ${ }^{3}$ More critique was issued on the housing market measures (phasing in of the tax deduction measures too slow, measures in the housing sector were to have limited impact and attention for households most in need was still work in progress). Despite the more critical tone in the assessment of housing policies, the actual recommendation was still cautiously worded, giving the national institutions ample flexibility to address the issue as they would see fit. No deadlines were mentioned and the recommendation enabled the Dutch authorities to wait until the 'economic environment' allowed for the implementation of the measures. The Commission and Council, furthermore, refrained from specifying the exact measures needed but left also this aspect to the Dutch government. In the 2015 CSR, the exact same recommendation reappeared, again without further specification or deadlines (European Commission 2015b, 5).

The Dutch parliament held a plenary debate on the NRP and budget plans upon the request of parliament. Much of the debate concentrated on the high level of private debt. Some motions on this issue were tabled, of which only one was adopted: on a 'fast reduction' of the private debt. However, this resolution did not result in a change of the NRP. Instead, the Minister of Finance promised to address the issue in the 'Miljoenennota' (Netherlands Budget Memorandum). Interestingly, the recommendation on the reduction of the private debt, seemingly a crucial issue in 2014, did not reappear in the CSR of 2015, although the issue certainly had not been resolved by that time (European Commission 2015b).

The private debt, the biggest concern in the eyes of the Tweede Kamer (Lower House), thus did not result in an amendment of the NRP. More generally, the impact of the Dutch 
parliament was rather limited. In the context of a debate on pensions, the Tweede Kamer had adopted a motion to retain national autonomy over the national pension system. This motion did not prevent the government from including its pension plans into the NRP nor the Commission and Council from responding to these plans. Moreover, the 2015 CSR even included a more specific recommendation to change the pension system (to reduce the level of contributions to the second pillar of the pension system for those in the early years of working life) (European Commission 2015b, 5). There are no indications to be derived from the formal documents that the Dutch governments has in any way put the parliamentary concerns to the attention of the Commission and the Council.

\subsection{France}

France was experiencing macroeconomic imbalances in 2014 as well and continued to do so afterwards (European Commission 2014c, 2014f). The French NRP of 2014 demonstrated an - albeit implicit - sense of the urgency of the issues facing the French economy. It elaborated plans to restore competitiveness (especially in specific fields of services provisions and in measures to enhance the export capacity of domestic businesses); to increase and boost economic growth; to reform the job market to encourage employment growth (in particular a number of measures already adopted or in the process of being adopted to lower the cost of labour for employers were elaborated) to improve purchasing power (the NRP discussed inter alia the 2014 Consumer law) and to reduce inequality and poverty (French Government 2014). A great deal of the actions announced were, however, less specific compared to the German and Dutch NRPs.

In contrast to the CSRs addressed to Germany and the Netherlands, the CSR addressed to France deviated considerably from the NRP. Moreover, France faced almost twice as many recommendations (7) as the Netherlands and Germany did. The CSR called upon France to ensure that labour costs were effectively reduced (by lowering social security contributions), and to reform the labour market (e.g. the conditions of the 'accords de maintien de l'emploi', the unemployment benefit system and vocational education and training). Also, specific measures to reform the tax system, simplification of rules ${ }^{4}$ and a better functioning of the market ${ }^{5}$ were required (Council of the European Union 2014c, 6).

The Commission and Council (apart from a couple of minor amendments, the Commission's proposal [European Commission 2014h] was almost identical to the eventual text of the CSR as adopted by the Council) thus took a more autonomous approach compared to the CSRs addressed to the Netherlands and Germany (Council of the European Union 2014c, 6). The recommendation to lower labour costs for business was still an endorsement of the measures announced by the French government. The recommendations on administrative simplification, however, went much further than the NRP. It singled out specific objectives, such as to 'eliminate regulatory impediments to companies' growth, in particular by reviewing size-related criteria in regulations to avoid thresholds effects'. The CSR also reiterated recommendations from previous years (such as to remove the prohibition to sell products at a loss) which had not been addressed in the NRP. More in general, with a list of seven recommendations the CSR created a clear hierarchy of priorities in the wide range of plans elaborated by the French government.

Other elements downplay the impact of the CSR, however. The CSR contained hardly any concrete measures that had not already been included in the NRP and no strict deadlines 
or even time frames for compliance were set, not even for the repeated recommendations. The latter were not even formulated in stricter terms than in prior years.

The Assemblée Nationale was relatively active on EMU issues in 2014. It has also become practice to adopt a parliamentary resolution on Stability and Reform Plans (Lupo and Fasone 2016 , 14). Following the announcement of Prime Minister Valls, the NRP, the NSP and the CSRs were discussed in parliament (Maatsch 2017, 704). Most of the attention went to the budget deficit, however. The meeting of the EAC with Pierre Moscovici, European Commissioner for Economic and Monetary Affairs on 14 October mainly concerned Mr. Moscovici's appointment as EU Commissioner, rather than a discussion of the NRP or CSR. The EAC of the Assemblée Nationale did produce a comprehensive report on the 2014 Stability and NRPs, however. It was drawn up by two rapporteurs and it discussed the government's plans in detail. The document was mainly meant for internal purposes: to provide MPs with information on the two programs. Interestingly, its conclusions reached well beyond the content of the NRP and the National Stability program (Commission Des Affaires Européennes 2014). The rapporteurs appealed to the Commission to respect national autonomy in terms of the time line as well as the means to achieve the objectives set by the CSR and called on the Commission to take environmental and social concerns better into account within the ES. However, they did not question the concrete measures of the NRP or the CSRs.

The rapporteurs also included a recommendation of particular relevance for the purposes of this article as it concerned how the Assemblée Nationale should be involved in the decision-making on EU economic policies. Given the need for parliamentary involvement in adopting NRPs and NSPs, they suggested to set up a working group to study the options for better procedures in terms of information provision but also to ensure that the government takes the position of the Assemblée Nationale into account. Furthermore, the government should ensure that parliament is involved in the dialogue with the Commission and should already be part of the decision-making process before the government adopts the programs.

In February 2015, the Commission took a next step in the procedure by concluding that the macroeconomic imbalances in France had to be qualified as 'excessive', meaning that 'decisive policy action and specific monitoring' was required (European Commission 2015b). This was just one step away from the activation of the EIP. Consequently, the 2016 CSR for the first time contained a clear deadline (end of 2016) for achieving the objectives laid down therein (European Commission 2016b, 7). Strikingly, the French parliament was less involved in the ES in 2015. The NRP was neither broadly discussed nor voted on (Maatsch 2017, 705).

\subsection{United Kingdom}

Also the UK economy suffered from imbalances in 2014. The European Commission had carried out an IDR and considered the high level of household debt, the housing market and, to a lesser extent, the trade account deficit as main concerns (European Commission 2014e and 2014g). In this context, the UK government adopted its NRP, which reflects the idea of EU economic governance being a continuous dialogue between EU and national institutions (HM Government 2014). It provides an in-depth overview of the national measures adopted to implement the 2013 CSR. These recommendations concerned the housing market, youth unemployment, poverty reduction, availability of financing to the corporate sector and network infrastructure investment. Furthermore, the NRP set out the policy 
measures the government pursued in line with the Europe 2020 Strategy. It addressed employment, education, social exclusion and poverty, research and innovation and climate change. In these fields, the government mainly referred to general objectives and existing measures however. The focus of the 2014 NRP was, moreover, on implementation and delivery of existing reform commitments (HM Government 2014, 7).

The CSRs 2014 were highly similar to those of the preceding year (Council of the European Union 2014b). As the UK government had addressed these previous CSRs elaborately, the 2014 CSR may largely be seen as endorsements of the NRP. The Council and Commission considered that the housing market problem should be addressed by'appropriate measures' to e.g. deal with the rapid increasing of property prices in some areas and to 'continue efforts' to increase the supply of housing. Regarding unemployment, the commitment to the Youth Contract should be maintained. Continuing existing efforts were equally demanded with regard to reducing child poverty, and increasing access to finance for SMEs. Lastly, the National Infrastructure Plan should be followed up.

Despite the existence of macroeconomic imbalances, the impact of EU institutions on UK economic performance policies is limited. The CSRs were mostly endorsements of national economic plans and measures. The level of specificity remains, furthermore, limited, even though the issues addressed are reoccurring. On the other hand, the UK government itself specified into considerable detail how it implemented previous CSRs, which made EU endorsement thereof more likely.

As regards parliamentary involvement, the UK NRP is the only one of the four analysed NRPs that explicitly recognized the need for 'substantial engagement with national Parliaments and the wider public'. The UK government considered this to be critical to the success of Europe 2020 (HM Government 2014, 7). It is equally interesting to note that the UK government considered that the principle of proportionality should govern the involvement of the British parliament and other stakeholders. This means that 'the type and scale of consultation' should be related to the potential impacts of the proposal or decision. Also, government put forward that 'real engagement' should be preferred over merely following bureaucratic process. This suggests that the government would seek substantive input from and discussion with Parliament. At the same time, government viewed that since the NRP did not contain any new policy announcements, it was not subject to formal consultation.

According to an in-depth analysis report from the Economic Governance Support Unit (European Parliament 2014), the House of Commons and the House of Lords have been active in debating the country's convergence programme and NRPs during the time period of 2013-2014. The European Scrutiny Committee of the House of Commons held a debate on 17 June 2013 which covered the Council's opinion on the NRP and the convergence programme.

The House of Commons pointed out in its 11 June meeting that there should ideally be two ES debates; respectively in March and June, both before European Council meetings. However, it also notes that the Government has not been supportive, or better, has ignored this recommendation. In this situation, they further recommended that the relevant documents, along with draft CSRs be debated before the June European Council (House of Commons 2014). 


\section{Discussion and conclusion}

There is a convincing argument to be made for a better involvement of national parliaments in EU economic performance policies. Accountability and input in the decision-making cannot, however, be seen in isolation from the impact of such policies. The UK parliament put forward that consultative requirements should be related to the potential impacts of policies. This principle may be broadened to democratic legitimacy in general. The old Broad Economic Policy Guidelines were not systematically scrutinized given their 'soft' nature. Has this situation fundamentally changed under the current framework of economic performance policies?

The analysis suggests that a distinction should be made between potential and actual impact. With regard to the potential of the new regimes, applicable since 2011, this allows EU institutions to influence Member States' economic performance policies considerably and, ultimately, even to enforce those policy choices. Economic performance may, moreover, include a wide range of issues and the exact policy objectives thereof are only defined in the policy dialogue between EU and national institutions. The assessment of the CSRs indeed demonstrated the breadth of issues and the lack of a clear prioritization by the Commission (apart perhaps from the trade surpluses of Germany and the Netherlands which were indeed qualified as major issues).

In practice, however, the impact of economic performance policies is still modest. Especially the Commission seems to be cautious not to step on Member States' toes. No sanctions have been applied yet, and also the steps towards more intensified forms of control have only been taken very cautiously, even in case of persistent inability to successfully implement CSRs. The case of Germany with its high account surplus is a case in point in this regard. It is also striking that the level of specificity of the studied CSRs remains generally limited. Even in cases of serious problems, the CSRs often lack clear deadlines and do not specify with great exactitude which measures should be adopted. There is no guarantee, however, that this cautious approach will not change. The more recent willingness of the Commission to qualify macroeconomic imbalances in France as excessive may suggest that the honeymoon period, allowing the Member States to gradually adapt to the new governance regime, may be nearing its end.

Another interesting observation is that the impact of EU economic performance policies varies among the Member States. This goes further than the formal differences in intensity of EU supervision (between programme countries receiving financial assistance, Member States with no macroeconomic imbalances/excessive imbalances/excessive imbalances with corrective action). Even though the studied CSRs regarded countries with macroeconomic imbalances, the approach of the Commission varied considerably. In case of Germany, the UK and the Netherlands, the Commission largely limited itself to endorsing the measures elaborated in NRPs. France, however, had to face stricter CSRs as well as CSRs which had not been included in the NRP. It is difficult to explain this stricter approach. The situation of the French economy was indeed difficult, but the Commission equally viewed the trade account surpluses in Germany and the Netherlands as serious economic problems, without this being translated into an equally strict approach. The UK, the Netherlands and Germany had adopted a more serious strategy to address economic issues themselves already, which may be an explanation for the different approach. In any case, the distinction between the UK as 
a non-Eurozone Member State vs. the others being part of the Eurozone has obviously been an irrelevant factor.

Such differences suggest that a single systematic approach to parliamentary involvement in EU economic performance policies is problematic. The demand for democratic legitimacy may vary depending on the economic situation, the level of supervision, but most notably it depends on the actual content of the policy dialogue. The analysis suggests in any case that NRPs are key policy documents for national parliaments as they are crucial for the development of substantive economic performance policies. There are more reasons why national parliaments could focus their attention best on NRPs. They are adopted early in the decision-making cycle, thereby increasing the chances of impacting the decision-making. And national governments are indeed key players in determining the content of national economic performance policies. Formally, these policies are part of EU wide measures, such as the Annual Growth Survey and the Europe 2020 Strategy. These are of a general nature though, and the 'right of initiative' to adopt concrete policies thus lies at the national level. Moreover, scrutiny of NRPs remains within the classic government-parliament relations and thus offers a familiar arena for holding the executive accountable.

At the same time, it may be likely that an upsurge in national parliaments' scrutiny of the ES, including NRPs will not emerge. Many NRPs contain measures which have already been adopted, discussed and/or planned. As the analysis showed, national parliaments have mostly already been involved in the adoption of such measures. The Dutch pension measures and tax deduction system for mortgages are examples in this regard (and see in this regard also the argument of the Danish government that a mandating system for NRPs and SCPs would not make sense as the latter represent the outcome of earlier negotiations with the Folketing: Buskjaer Rasmussen 2018). If a NRP is simply a collection of such measures it is unlikely, and indeed also unnecessary, for it to attract much parliamentary attention. This is equally true if a NRP contains only general plans.

A complicating factor to assess the impact of EU economic performance policies is that the ES may be an annual policy cycle, but it actually represents a permanent and continuous system of policy dialogue now. It builds on previous years and is followed up upon in subsequent years. This leads to an incremental shaping of economic policies, as the gradually stricter approach towards the German trade account surplus demonstrates. This makes it for parliaments more difficult to assess which are the defining moments on which the parliamentary attention should be directed.

The reactions of the four parliaments reflect the difficulties of ensuring adequate democratic legitimacy and the effects of the complicating factors as they have been outlined above. In all four parliaments, the need for better parliamentary involvement in adopting economic performance policies, however, came to be acknowledged around 2014. NRPs were discussed in plenary sessions and other ways to scrutinize these policies with their governments were developed. The effects thereof, especially in actually providing input on the content of economic policies remained modest, despite concrete efforts made to this end. This has also been an issue of timing. Commonly, national parliaments received NRPs just before they are sent to the Commission. As the Dutch example demonstrated, it is difficult to get any concrete changes through at that point. They would thus have better chances if their input would be ensured before the adoption of the NRP, as was acknowledged in the Assemblée Nationale. 
The impact of EU economic performance policies is a relevant factor for national parliaments' involvement in these policies. Given scarcity of time and resources, it makes sense for parliaments to limit their attention to policies that indeed have a substantial impact on and in the Member States. This contribution demonstrated that parliaments indeed consider the impact of these policies. At the same time, however, it has been shown how difficult it may be in practice to determine the exact impact of economic performance policies as the extent to which Member States' autonomy has been limited in this field, is not easy to establish. Moreover, such impact may vary among Member States and across time. This suggests that a single model of parliamentary involvement would be both unfeasible and undesirable, although the democratic challenge in EU economic performance is overall increasing

These findings shed new light on the throughput legitimacy perspective and underscore the relevance thereof. Indeed, the throughput perspective is key as the ES raises important questions on the quality of the procedures because of its complexity. In examining how EU and national actors interact in EU economic performance policies, this contribution has sought to contribute to the assessment of the quality of the ES procedures. But what is more, the findings suggest that another dimension should be included in a throughput perspective. Accountability, openness and efficacy are the main elements to assess throughput legitimacy. These elements suggest that a sufficient level of clarity should be achieved in the relation between the actors involved. They also suggest, however, that the relevance, the meaning and the impact of the various measures adopted should be sufficiently clear. In this light, it must be observed that from a throughput perspective the adoption of EU economic performance policies still leaves much to be desired.

\section{Notes}

1. The issue of economic governance within an asymmetric EMU has been discussed extensively. For an evaluation of literature see Jabko (2011). For an historical analysis of the Franco-German debate concerning the appropriate EMU architecture see (Pisani-Ferry 2006); see also (Schelkle 2006).

2. https://www.gruene-bundestag.de/parlament/bundestagsreden/2014/april/katharinadroege-nationales-reformprogramm.html.

3. Interestingly, the CSR 2015 did not include recommendations on the reform of the labour market and labour market participation anymore.

4. Especially of companies' administrative, fiscal and accounting rules and innovation policies.

5. Opening up of regulated professions, diminish regulatory burdens for the retail market, special recommendations for the energy market.

\section{Disclosure statement}

No potential conflict of interest was reported by the author.

\section{References}

Adnett, N. 2001. "Modernizing the European Social Model: Developing the Guidelines." Journal of Common Market Studies 39 (2): 353-364.

Amtenbrink, F. 2012."Legal Developments." Journal of Common Market Studies 50 (Suppl. 2): 132-146. Armstrong, K. 2013. "The New Governance of EU Fiscal Discipline." European Law Review 38 (5): 601-617. Barrett, K. 2018. "European Economic Governance: Deficient in Democratic Legitimacy?" Journal of European Integration. 
Bekker, S. 2014. "EU Economic Governance in Action: Coordinating Employment and Social Policies in the Third European Semester." OSE Research Paper No. 19.

Buskjaer Rasmussen, M. 2018. "Accountability Challenges in EU Economic Governance? Parliamentary Scrutiny of the European Semester." Journal of European Integration.

Commission Des Affaires Européennes, Assemblée Nationale. 2014. Rapport d'information No. 2056. Les recommendations sur les programmes Francais de stabilité et de réforme pour 2014, DIAN 44/2014.

Costamagna, F. 2013. “The European Semester in Action: Strengthening Economic Policy Coordination While Weakening the Social Dimension?" LPF-WEL Working Paper No. 5.

Council of the European Union. 2014a. Council Recommendation of 8 July 2014 on the National Reform Programme 2014 of the Netherlands and delivering a Council Opinion on the Stability Programme of the Netherlands. OJ C 247/17.

Council of the European Union. 2014b. Council Recommendation of 8 July 2014 on the National Reform Programme 2014 of the United Kingdom and delivering a Council opinion on the Convergence Programme of the United Kingdom. OJ C 247/136.

Council of the European Union. 2014c. Recommendation for a Council Recommendation on the National Reform Programme 2014 of France and delivering a Council opinion on the Stability Programme, 2014. OJ C 247/42.

Craig, P. P. 2012. "The Stability, Coordination and Governance Treaty: Principle, Politics and Pragmatism." European Law Review 37: 231.

Crum, B. 2017. "Parliamentary Accountability in Multilevel Governance: What Role for Parliaments in Post-Crisis EU Economic Governance?" Journal of European Public Policy 25 (2): 268-286.

Crum, B., and D. Curtin. 2015. "The Challenge of Making European Union Executive Accountable." In The European Union: Democratic Principles and Institutional Architectures in Times of Crisis, edited by S. Pattioni, 63. Oxford: University Press.

Curtin, D. 2014. "Challenging Executive Dominance in European Democracy." Modern Law Review 77: $1-32$.

De Sadeleer, N. M. 2012. “The New Architecture of the European Economic Governance: A Leviathan or a Flat-Footed Colossus?" Maastricht Journal of European and Comparative Law 19 (3): 354-383.

Deutscher Bundestag. 2015. Nationales Reformprogramm 2015 - Wirtschaftspolitische Steuerung in der EU ernst nehmen und Investitionen stärken. Drucksache 18/4464. http://dip21.bundestag.de/dip21/ btd/18/044/1804464.pdf.

Dutch government, Ministry of Economic Affairs. 2014. National Reform Programme 2014 the Netherlands. The Hague. http://ec.europa.eu/europe2020/pdf/csr2014/nrp2014_netherlands_en.pdf

European Commission. 2014a. Macroeconomic Imbalances Germany 2014. Occasional Papers 174. Brussels. http://ec.europa.eu/economy_finance/publications/occasional_paper/2014/pdf/ocp174_ en.pdf.

European Commission. 2014b. Assessment of the 2014 National Reform Programme and Stability Programme for Germany Accompanying the Document Recommendation for a Council Recommendation on Germany's 2014 National Reform Programme and Delivering a Council Opinion on Germany's 2014 Stability Programme. SWD(2014) 406 final. http://ec.europa.eu/europe2020/pdf/csr2014/swd2014_ germany_en.pdf.

European Commission. 2014c. Macroeconomic Imbalances Netherlands 2014. Occasional Paper 185. Brussels. http://ec.europa.eu/economy_finance/publications/occasional_paper/2014/pdf/ocp185_ en.pdf.

European Commission. 2014d. Recommendation for a Council Recommendation on the Netherlands' 2014 National Reform Programme and Delivering a Council Opinion on the Netherlands' 2014 Stability Programme. COM(2014) 420 final. http://ec.europa.eu/europe2020/pdf/csr2014/csr2014_ netherlands_en.pdf.

European Commission. 2014e. Commission Concludes in-depth Reviews to Identify Macroeconomic Imbalances and Assesses Progress in Fiscal Consolidation. Press Release. http://europa.eu/rapid/pressrelease_IP-14-216_en.htm.

European Commission. 2014f. Macroeconomic Imbalances France 2014. Occasional Papers 178. Brussels. http://ec.europa.eu/economy_finance/publications/occasional_paper/2014/pdf/ocp178_en.pdf.

European Commission. 2014g. Macroeconomic Imbalances United Kingdom 2014. Occasional Paper 188. Brussels. 
European Commission. 2014h. Recommendation for a Council Recommendation on France's 2014 National Reform Programme and Delivering a Council Opinion on France's 2014 Stability Programme. COM(2014) 411 final. http://ec.europa.eu/europe2020/pdf/csr2014/csr2014_france_en.pdf.

European Commission. 2015a. Country Report Germany 2015 Including an In-depth Review on the Prevention and Correction of Macroeconomic Imbalances. SWD(2015) 25 final/2. http://ec.europa. eu/europe2020/pdf/csr2015/cr2015_germany_en.pdf.

European Commission. 2015b. Country Report Netherlands 2015 Including an In-depth Review on the Prevention and Correction of Macroeconomic Imbalances. SWD(2015) 38 final. http://ec.europa.eu/ europe2020/pdf/csr2015/cr2015_netherlands_en.pdf.

European Commission. 2015c. Country Report France 2015 Including an In-depth Review on the Prevention and Correction of Macroeconomic Imbalances. SWD(2015) 29 final. http://ec.europa.eu/europe2020/ pdf/csr2015/cr2015_france_en.pdf.

European Commission. 2016a. Fact sheet: The EU's Economic Governance Explained. https://ec.europa. eu/info/files/fact-sheet-eus-economic-governance-explained_en.

European Commission. 2016b. Recommendation for a Council Recommendation on the 2016 National Reform Programme of France and Delivering a Council Opinion on the 2016 Stability Programme of France. COM(2016) 330 final. http://ec.europa.eu/europe2020/pdf/csr2016/csr2016_france_en.pdf.

European Commission. 2016c. Country Report France 2016 Including an In-depth Review on the Prevention and Correction of Macroeconomic Imbalances. SWD(2016) 79 final. http://ec.europa.eu/europe2020/ pdf/csr2016/cr2016_france_en.pdf.

European Parliament. 2014. Involvement of National Parliaments in SCP and NRP 2013 and 2014. EGOV 2014. http://www.europarl.europa.eu/document/activities/cont/201409/20140917ATT89184/20140 917ATT89184EN.pdf.

Federal Ministry for Economic Affairs and Energy. 2014. National Reform Programme 2014. Berlin. http:// ec.europa.eu/europe2020/pdf/csr2014/nrp2014_germany_en.pdf.

French Government. 2014. Programme national de réforme Mai 2014. Paris. http://ec.europa.eu/ europe2020/pdf/csr2014/nrp2014_france_fr.pdf.

German government, Federal Ministry of Economic Affairs and Energy. 2014. National Reform Programme 2014. Berlin. http://ec.europa.eu/europe2020/pdf/csr2014/nrp2014_germany_en.pdf.

Hallerberg, M., B. Marzinotto, and G. B. Wolff. 2011. "How Effective and Legitimate is the European Semester? Increasing the Role of the European Parliament." Bruegel Working Paper, No. 2011/09.

HM Government. 2014. Europe 2020: UK National Reform Programme 2014. http://ec.europa.eu/ europe2020/pdf/csr2014/nrp2014_uk_en.pdf.

House of Commons. 2014. Meeting of 11 June 2014 for Debate in European Committee B, with other European Semester Documents, before the June 2014 European Council at https://www.publications. parliament.uk/pa/cm201415/cmselect/cmeuleg/219-ii/21904.htm.

Jabko, N. 2011. Which Economic Governance? Facing up to the Problem of Divided Sovereignty, SIEPS Report 2011:2. Stockholm: SIEPS.

Juncker, Jean-Claude, in close cooperation with D. Tusk, J. Dijsselblom, M. Draghi, and M. Schulz. 2015. Completing Europe's Economic and Monetary Union. Brussels: Five Presidents' Report.

Kreilinger, V. 2018. "Normal and Exceptional Activities of National Parliaments in EU Economic Governance." Journal of European Integration.

Lupo, N., and C. Fasone, eds. 2016. Introduction. Parliaments in the Composite European Constitution: Hart Publishing.

Maatsch, A. 2017. "Effectiveness of the European Semester: Explaining Domestic Consent and Contestation." Parliamentary Affairs 70 (4): 691-709.

Peña-Casas, R., S. Sabato, V. Lisi, and C. Agostini. 2015. The European Semester and Modernisation of Public Administration. OSE Paper Series, Briefing Paper No.12. Brussels: European Social Observatory.

Pisani-Ferry, J. 2006. "Only One Bed for Two Dreams: A Critical Retrospective on the Debate over the Economic Governance of the Euro Area." Journal of Common Market Studies 44 (4): 823-844.

Schelkle, W. 2006. "The Theory and Practice of Economic Governance in EMU Revisited: What Have we Learnt About Commitment and Credibility?" Journal of Common Market Studies 44 (4): 669-864.

Zeitlin, J., and B. Vanhercke. 2014. "Socializing the European Semester? Economic Governance and Social Policy Coordination in Europe 2020." Watson Institute for International Studies Research Paper No. 2014-17. 